\title{
PENERAPAN MODEL THINK PAIR SHARE BERBANTUAN MEDIA UNTUK MENINGKATKAN AKTIVITAS, SIKAP, DAN HASIL BELAJAR IPS
}

\author{
Muhamad Ngafifi, Siti Irene Astuti D \\ SMP Negeri 2 Sukoharjo Wonosobo, Universitas Negeri Yogyakarta \\ afivejausyaq@gmail.com, ireneast@yahoo.com
}

\begin{abstract}
Abstrak
Penelitian ini bertujuan untuk meningkatkan: (1) Aktivitas Belajar Siswa, (2) Sikap Siswa, dan (3) Hasil Belajar IPS siswa kelas VIII B SMP Negeri 2 Sukoharjo, Wonosobo. Penelitian ini merupakan penelitian tindakan kelas (PTK) yang terlaksana dalam dua siklus dengan menggunakan desain Kemmis \& Taggart. Teknik pengumpulan data yang digunakan adalah observasi, tes hasil belajar, angket, dokumentasi, dan catatan lapangan. Teknik analisis data menggunakan analisis deskriptif kuantitatif. Hasil penelitian ini adalah: (1) Terjadi peningkatan aktivitas belajar siswa; pada akhir siklus I dengan rata-rata 67,84 menjadi 81,20 pada akhir siklus II. (2) Ada peningkatan nilai sikap siswa. Rata-rata nilai sikap siswa pada akhir siklus I 77,20 menjadi 84,49 pada akhir siklus II. (3) Terjadi Peningkatan hasil belajar dari kondisi awal dengan nilai rata-rata 65,58, pada akhir siklus I menjadi 79,10, dan pada akhir siklus II menjadi 85,90.
\end{abstract}

Kata Kunci: model Think Pair Share, media pembelajaran, hasil belajar

\section{THE IMPLEMENTATION OF MEDIA-AIDED THINK PAIR SHARE MODEL TO IMPROVE ACTIVITIES, ATTITUDE, AND LEARNING OUTCOMES IN SOCIAL STUDIES}

\author{
Muhamad Ngafifi, Siti Irene Astuti D \\ SMP Negeri 2 Sukoharjo Wonosobo, Universitas Negeri Yogyakarta \\ afivejausyaq@gmail.com, ireneast@yahoo.com
}

\begin{abstract}
This study aims to improve: (1) the students'learning activities, (2) the students'attitude, and (3) the learning outcome of class VIII B, SMP Negeri 2 Sukoharjo, Wonosobo. This study is classroom action research (CAR) consisting of two cycles, using Kemmis \& Taggart design. The data collection techniques used were observation, achievement test, questionnaire, documentation, and field note. The data analysis used the quantitative descriptive analysis. The results are as follows. (1) There is an increase in students' learning activities; at the end of the first cycle, the average score of students' activities was 67.84 and it became 81.20 in cycle II. (2) There is an increase in students'attitude. The average of students' attitude score was 77.20 in cycle I and it became 84.49 in cycle II. (3) There is an increasing of cognitive learning outcome; in the precycle, the average score of cognitive learning outcome was 65.58, in the cycle I it became 79.10, and in the cycle II it became 85.90.
\end{abstract}

Keywords: Think Pair Share model, instructional media, learning outcome 


\section{Pendahuluan}

Pendidikan merupakan aspek kehidupan fundamental bagi pembangunan nasional, investasi masa depan bangsa dan indikator kemajuan suatu negara. Oleh karena itu, penyelenggaraan pendidikan di Indonesia harus mampu menjamin pemerataan kesempatan pendidikan, peningkatan mutu, relevansi, dan efisiensi manajemen pendidikan. Hal ini dimaksudkan supaya tidak terjadi kesenjangan tingkat pendidikan di antara satu daerah dengan daerah lainnya.

Undang-Undang No 20 Tahun 2003 Pasal 1 ayat (1) tentang Sistem Pendidikan Nasional menyebutkan bahwa: Pendidikan merupakan usaha sadar dan terencana untuk mewujudkan suasana belajar dan proses pembelajaran agar peserta didik secara aktif mengembangkan potensi dirinya untuk memiliki kekuatan spiritual keagamaan, pengendalian diri, kepribadian, kecerdasan, akhlak mulia, serta keterampilan yang diperlukan bagi dirinya, masyarakat, bangsa, dan negara.

Pada era globalisasi semua negara berupaya meningkatkan kualitas pendidikan. Melalui pendidikan, kualitas sumber daya manusia dapat ditingkatkan, sehingga kesejahteraan masyarakat diharapkan dapat meningkat. Lembaga pendidikan, seperti sekolah-sekolah mempunyai peran penting dalam menghasilkan sumber daya manusia berkualitas yang mampu mengelola sumber daya alam secara efektif, efisien, dan memberi jasa layanan yang baik (Mardapi, 2012, p.1). Dengan demikian, semua lembaga pendidikan di Indonesia harus berusaha untuk meningkatkan kemampuan lulusannya agar mampu bersaing di tingkat lokal, regional maupun global.

Hal ini sesuai dengan fungsi dan tujuan pendidikan nasional sebagai berikut: Pendidikan nasional berfungsi mengembangkan kemampuan dan membentuk watak serta peradaban bangsa yang bermartabat dalam rangka mencerdaskan kehidupan bangsa. Tujuan pendidikan nasional adalah untuk berkembangnya potensi peserta didik agar menjadi manusia yang beriman dan bertakwa kepada Tuhan Yang Maha Esa, berakhlak mulia, sehat, berilmu, cakap, kreatif, mandiri, dan menjadi warga negara yang demokratis serta bertanggung jawab (UU Sisdiknas, 2003, p.3).
Permasalahan pendidikan pada abad ke-21 semakin kompleks, di antaranya guru harus mampu mengajar dalam masyarakat multikultur, mengajar untuk konstruksi makna, mengajar untuk pembelajaran aktif, mengajar dengan teknologi, dan akuntabilitas guru dalam mengajar (Arends, 2012, p.8). Hasil belajar diharapkan meliputi pola kompetensi dan intelegensi yang dibutuhkan untuk berkiprah pada abad ke-21. Pendidikan bukan hanya menyiapkan masa depan, tetapi bagaimana menciptakan masa depan. Pendidikan harus membantu terciptanya individu kritis dengan tingkat kreativitas dan keterampilan berpikir yang lebih tinggi serta proses pembelajaran sepanjang hayat (life long education).

Pandangan bahwa mengajar hanya sebatas menyampaikan ilmu pengetahuan, dianggap sudah tidak relevan dengan keadaan. Ada tiga alasan mengenai hal itu; pertama, siswa adalah organisme yang sedang berkembang. Agar siswa dapat melaksanakan tugas-tugas perkembangannya, dibutuhkan orang dewasa yang dapat mengarahkan dan membimbingnya supaya tumbuh dan berkembang secara optimal. Kedua, kemajuan ilmu pengetahuan mengakibatkan kecenderungan setiap orang tidak mungkin dapat menguasai setiap cabang keilmuan. Ketiga, penemuan-penemuan baru khususnya dalam bidang psikologi, mengakibatkan pemahaman baru terhadap konsep perubahan tingkah laku manusia. Ketiga hal tersebut menuntut perubahan makna dalam mengajar. Mengajar jangan diartikan sebagai proses menyampaikan materi pembelajaran, atau memberikan stimulus sebanyak-banyaknya kepada siswa, akan tetapi lebih dipandang sebagai proses mengatur lingkungan agar siswa belajar sesuai dengan kemampuan dan potensi yang dimilikinya (Sanjaya, 2012, pp.100-102).

Heinich, et al (2002, pp.7-8) mendefinisikan pembelajaran sebagai berikut: Intruction is the arrangement of information and environment to facilitate learning. By environment we mean not only where instruction takes place but also the methods, media, and equipment needed to convey information and guide the learner's study. Artinya, Pembelajaran merupakan penataan informasi dan lingkungan guna memudahkan belajar. Lingkungan yang dimaksud, tidak hanya 
tempat di mana pembelajaran itu berlangsung, tetapi juga model, media, dan peralatan yang diperlukan untuk menyampaikan informasi dan mengarahkan belajar para pembelajar.

Guru memiliki multi peran dalam proses pembelajaran antara lain; guru dapat berperan sebagai pengajar, pemimpin kelas, pembimbing, pengatur lingkungan belajar, perencana pembelajaran, supervisor, motivator, dan sebagai evaluator. Guru merupakan faktor penentu yang sangat dominan dalam pendidikan pada umumnya, karena guru memegang peranan dalam pembelajaran yang merupakan inti dari proses pendidikan secara keseluruhan.

Pada dasarnya guru harus mampu membantu kesulitan-kesulitan yang dihadapi siswanya dalam proses pembelajaran, untuk itu guru dituntut untuk mengenal lebih dekat kepribadian siswanya. Guru harus mampu melakukan proses identifikasi terhadap keadaan siswa untuk dievaluasi agar lebih konkret dan mendekati tepat dalam memahami keadaan siswanya. Diharapkan jika guru telah mengetahui kondisi siswanya akan mempermudah memberikan materi pelajaran sesuai dengan kebutuhan, minat, dan bakat siswa (Rusman, 2011, p.58).

Sesuai dengan tanggung jawab profesional guru, maka dalam melaksanakan kegiatan pembelajaran setiap guru dituntut untuk selalu menyiapkan segala sesuatu yang berhubungan dengan program pembelajaran. Tujuannya adalah agar kegiatan pembelajaran dapat berjalan secara efektif dan efisien, yaitu tujuan akhir yang diharapkan dapat dikuasai oleh semua siswa (Uno\&Mohamad, 2012, p 3). Oleh karena itu, dalam pengelolaan kelas guru harus memiliki kemampuan untuk menciptakan suasana kondusif di kelas sehingga pembelajaran menyenangkan.

Cara penerapan suatu pembelajaran akan berpengaruh besar terhadap kemampuan siswa dalam mendidik diri mereka sendiri. Guru yang sukses bukan sekedar penyaji yang kharismatik dan persuasif. Lebih jauh, guru yang sukses mampu melibatkan siswa dalam tugas-tugas yang sarat muatan kognitif dan sosial, dan mengajari siswa bagaimana mengerjakan tugas-tugas tersebut secara produktif. Guru yang sukses senantiasa mengajari siswa bagaimana menyerap dan menguasai informasi yang berasal dari penjelasannya. Sedangkan siswa yang efektif mampu menggambarkan informasi, gagasan, dan kebijaksanaan dari guru-gurunya dan menggunakan sumber-sumber pembelajaran secara efektif. Dengan demikian, peran utama dalam mengajar adalah mencetak pembelajar yang handal (Joyce \& Weil, 2011, p.7).

Di era globalisasi sekarang ini, diperlukan pengetahuan dan keanekaragaman keterampilan guru agar siswa mampu memberdayakan dirinya. Hal ini diperlukan agar siswa mampu menemukan, menafsirkan, menilai, dan menggunakan informasi serta melahirkan gagasan kreatif untuk menentukan sikap dalam pengambilan keputusan (Rusman, 2011, p.105). Dengan demikian, diperlukan kemampuan profesional guru dalam melakukan kegiatan pembelajaran yang efektif dan efisien. Pembelajaran yang efektif membutuhkan pemikiran seksama dan reflektif tentang apa yang dikerjakan guru dan efek tindakannya pada pembelajaran sosial dan akademik siswa. Guruguru masa kini harus bertanggung jawab atas praktik mengajarnya dan atas apa yang dipelajari oleh siswa.

Trianto (2012, p.5) menyatakan bahwa proses pembelajaran akan efektif apabila dilakukan melalui persiapan dan direncanakan dengan baik supaya dapat diterima untuk memenuhi: (1) kebutuhan masyarakat setempat dan masyarakat global, (2) mempersiapkan siswa dalam menghadapi perkembangan dunia global, dan (3) sebagai proses untuk melanjutkan ke jenjang yang lebih tinggi. Sementara itu, penyelenggaraan pendidikan dapat dikatakan berhasil apabila kegiatan belajar mampu membentuk pola tingkah laku siswa sesuai dengan tujuan pendidikan, serta dapat dievaluasi melalui pengukuran dengan menggunakan tes dan non tes.

Ilmu Pengetahuan Sosial (IPS), termasuk dalam kelompok mata pelajaran ilmu pengetahuan dan teknologi yang diajarkan secara terpadu. National Council for the Social Studies (NCSS) (2008, p.211), mendefinisikan IPS sebagai berikut: Social studies is the integrated study of the social sciences and humanities to promote civic competence. Within the school program, social studies provides coordinated, systematic study drawing upon such diciplines as anthropology, archeology, economic, geography, history, 
law, philosophy, political science, psychology, religion, and sociology, as well as appropriate content from the humanities, mathematics, and natural sciences.

Tujuan utama IPS ialah untuk mengembangkan potensi siswa agar peka terhadap masalah sosial yang terjadi di masyarakat, memiliki sikap mental positif terhadap perbaikan segala ketimpangan yang terjadi, dan terampil mengatasi setiap masalah yang terjadi seharihari baik yang menimpa dirinya sendiri maupun yang menimpa masyarakat. Tujuan tersebut dapat dicapai manakala program-program pelajaran IPS di sekolah diorganisasikan secara baik. Pada jenjang SMP pelajaran IPS dimaksudkan untuk memperoleh kompetensi dasar ilmu pengetahuan dan teknologi serta membudayakan berpikir ilmiah secara kritis, kreatif dan mandiri.

Proses pembelajaran IPS dalam sistem kurikulum saat ini, menuntut adanya partisipasi aktif dari seluruh siswa. Kegiatan belajar hendaknya berpusat pada siswa, sedangkan guru berperan sebagai motivator dan fasilitator agar suasana kelas lebih hidup. Dalam hal ini, diperlukan guru kreatif yang dapat membuat pembelajaran menjadi lebih menarik dan disukai oleh siswa. Suasana kelas perlu direncanakan dan dibangun sedemikian rupa dengan menggunakan model pembelajaran yang tepat agar siswa dapat memperoleh kesempatan untuk berinteraksi satu sama lain sehingga dapat diperoleh hasil belajar yang optimal. Dengan demikian, guru IPS dituntut dapat memilih model pembelajaran yang dapat memacu semangat setiap siswa untuk secara aktif ikut terlibat dalam pengalaman belajarnya.

Salah satu alternatif model pembelajaran IPS yang memungkinkan dikembangkannya keterampilan berpikir siswa adalah model pembelajaran kooperatif. Belajar kooperatif adalah kegiatan yang berlangsung dalam lingkungan belajar berbentuk kelompok kecil, sehingga siswa dapat saling berbagi ide dan bekerja secara kolaboratif untuk menyelesaikan tugas akademik (Davidson \& Kroll, 1991, p.362).

Belajar kooperatif sesuai dengan paradigma bahwa disamping makhluk individu, manusia adalah makhluk sosial yang tidak bisa berdiri sendiri, namun selalu membutuhkan kerja sama dengan orang lain. Belajar kooperatif tidak hanya bertujuan memahamkan siswa terhadap materi yang akan dipelajari namun lebih menekankan pada melatih siswa untuk mempunyai kemampuan sosial. Kemampuan sosial yang dimaksud yaitu kemampuan untuk saling bekerjasama, saling memahami, berbagi informasi, saling membantu antar teman kelompok, dan bertanggung jawab terhadap sesama teman kelompok untuk mencapai tujuan umum kelompok. Di dalam belajar kooperatif tidak hanya dituntut keberhasilan individu namun juga keberhasilan kelompok. Dari pemikiran itulah pada belajar kooperatif, siswa belajar dalam kelompok kecil yang bersifat heterogen dari segi kemampuan akademik, saling membantu satu sama lain dalam mencapai tujuan bersama (Slavin, 1995, p.2).

Kenyatannya proses pembelajaran yang dilakukan oleh banyak guru IPS saat ini cenderung pada pencapaian target materi kurikulum, lebih mementingkan pada hafalan bukan pada pemahaman konsep dan kecakapan hidup (life skill). Hal ini dapat dilihat dari kegiatan pembelajaran di dalam kelas yang selalu didominasi oleh guru. Dalam penyampaian materi, guru menggunakan model ceramah, sedangkan siswa hanya duduk, mencatat, dan mendengarkan apa yang disampaikan guru dan sedikit peluang bagi siswa untuk bertanya. Dengan demikian, suasana pembelajaran menjadi tidak kondusif sehingga siswa menjadi pasif.

Berdasarkan prasurvei pembelajaran IPS di kelas VIII B SMP Negeri 2 Sukoharjo Kabupaten Wonosobo, diperoleh bahwa ketika pelaksanaan pembelajaran IPS berlangsung, siswa belum melakukan aktivitas belajar dengan baik. Selama kegiatan pembelajaran guru belum mengembangkan potensi siswa sehingga siswa belum mampu mencapai kompetensi individidual yang diperlukan untuk mengikuti materi pembelajaran berikutnya. Siswa baru mempelajari hafalan istilah-istilah, belum sampai pada konsep, prinsip, hukum, teori, dan gagasan inovatif lainnya. Siswa juga belum dapat menggunakan dan menerapkan secara efektif manfaat pembelajaran IPS dalam pemecahan masalah sehari-hari. Jika masalah seperti ini dibiarkan terus-menerus, lulusan sekolah sebagai generasi penerus akan kesulitan dalam menghadapi persaingan hidup di era globalisasi. 
Guru IPS di SMP Negeri 2 Sukoharjo Kabupaten Wonosobo juga masih menggunakan model pembelajaran konvensional dengan mengandalkan ceramah sehingga siswa menjadi pasif karena pembelajaran berpusat pada guru (teacher centered). Pembelajaran IPS konvensional juga mengakibatkan siswa merasa bosan dan kurang tertarik untuk belajar IPS. Dalam pembelajaran konvensional siswa dipandang sebagai objek yang tidak bergerak, padahal pembelajaran yang baik seharusnya menempatkan siswa sebagai subjek dan pembelajaran berpusat pada siswa (student oriented). Selain itu, guru belum menggunakan media pembelajaran yang bervariasi sehingga sehingga pembelajaran IPS menjadi tidak efektif. Media pembelajaran yang biasa digunakan oleh guru antara lain; peta, atlas, dan globe. Rendahnya kemauan guru untuk melakukan inovasi dalam pemanfaatan dan penggunaan media membuat pelajaran IPS menjenuhkan. Dampaknya hasil belajar siswa kelas VIII B masih tergolong rendah.

Pada materi IPS kelas VIII semester 1 terdapat beberapa Kompetensi Dasar (KD) yang sulit bagi siswa sehingga perolehan hasil belajarnya rendah. Materi pelajaran yang cenderung rendah hasil belajarnya antara lain; kondisi fisik wilayah Indonesia, kondisi penduduk Indonesia, permasalahan kuantitas dan kualitas penduduk di Indonesia, permasalahan lingkungan hidup dan pelestariannya, dan perkembangan kolonialisme Barat di Indonesia. Sebagian besar siswa kelas VIII B belum mencapai Kriteria Ketuntasan Minimum (KKM) pada materi pembelajaran tersebut sehingga hasil belajar siswa masih rendah.

Rendahnya hasil belajar IPS kelas VIII B ditunjukkan dari hasil analisis ulangan harian yang telah didokumentasikan dalam daftar nilai pada kompetensi dasar 1.2 mengidentifikasi permasalahan kependudukan di Indonesia dan upaya penanggulangannya. Dari 22 siswa dengan Kriteria Ketuntasan Minimum (KKM) 77, diperoleh hasil 10 siswa $(45,45 \%)$ mendapatkan nilai $\geq K K M$, dan 12 siswa $(54,55 \%)$ mendapatkan nilai $\leq$ KKM. Nilai tertinggi yang diperoleh siswa adalah 90 sedangkan nilai terendahnya 40 dan rata-rata hasil ulangan harian yaitu 65,58. Dari hasil ulangan harian itu dapat diketahui bahwa hasil belajar IPS di kelas VIII B belum tuntas karena nilai rata-rata ulangan hariannya di bawah KKM. Hasil belajar siswa juga menitikberatkan pada ranah kognitif sedangkan ranah afektif, dan psikomotor belum dikembangkan secara seimbang.

Suasana pembelajaran IPS di kelas VIII B belum mencerminkan adanya interaksi edukatif di antara guru dan siswa. Guru mendominasi pembelajaran dengan menyampaikan materi dari awal hingga akhir pembelajaran sehingga yang terjadi bukan interaksi edukatif tetapi one way communication. Guru IPS di SMP Negeri 2 Sukoharjo menyatakan bahwa jika dilakukan pembelajaran yang berpusat pada siswa, materi tidak selesai sehingga target kurikulum tidak dapat berjalan sesuai dengan yang diharapkan.

Salah satu upaya untuk mengatasi permasalahan tersebut adalah melalui penerapan model pembelajaran kooperatif Think-Pair-Share (TPS) yang berarti berpikir-berpasangan-berbagi. Think Pair Share (TPS) merupakan jenis pembelajaran kooperatif yang dirancang untuk mempengaruhi pola interaksi siswa. Think Pair Share (TPS) merupakan salah satu model pembelajaran yang dikembangkan dari teori konstruktivisme yang merupakan perpaduan antara belajar secara mandiri dan belajar secara berkelompok. Think Pair Share memiliki prosedur yang ditetapkan secara eksplisit untuk memberi siswa waktu lebih banyak untuk aktif dalam pembelajaran melalui kegiatan berpikir, berpasangan, dan berbagi (Lie, 2003, p.57).

Penerapan model pembelajaran think pair share dapat lebih efektif dengan memanfaatkan media pembelajaran. Media pembelajaran dapat mempermudah penyampaian materi, merangsang pikiran, perasaan, minat, dan perhatian siswa sehingga interaksi edukatif dapat berjalan dengan baik. Media pembelajaran yang digunakan dalam penelitian ini yaitu; 1) handout materi permasalahan kependudukan dan lingkungan hidup yang bertujuan untuk meningkatkan pemahaman konsep, 2) gambar diam tentang permasalahan kuantitas dan kualitas penduduk di Indonesia, 3) peta konsep bergambar yang bertujuan untuk meningkatkan aktivitas belajar siswa, dan 4) video tentang permasalahan lingkungan hidup dan upaya pelestariannya. Melalui penerapan 
model pembelajaran think pair share berbantuan media handout, gambar diam, peta konsep bergambar, dan video pada pembelajaran IPS, dapat mendorong siswa untuk memiliki keterampilan sosial yang baik, yaitu berkomunikasi, bertanya, berpartisipasi maupun dalam keterampilan proses kelompok. Dengan demikian, aktivitas, sikap, dan hasil belajar IPS di SMP Negeri 2 Sukoharjo Kabupaten Wonosobo dapat meningkat.

Berdasarkan paparan tersebut maka penelitian ini bertujuan untuk meningkatkan: (1) aktivitas belajar siswa, (2) sikap siswa, (3) hasil belajar IPS siswa kelas VIII B SMP Negeri 2 Sukoharjo, Wonosobo.

\section{Metode Penelitian}

Jenis Penelitian

Penelitian ini merupakan Penelitian Tindakan Kelas (PTK) atau Classroom Action Research (CAR). Penelitian menggunakan desain Kemmis \& Taggart yang masing-masing terdiri atas tahap-tahap: kegiatan perencanaan (plan), pelaksanaan tindakan dan observasi (act \& observe), dan refleksi (reflect) (Kemmis \& Taggart, 1990, pp.11-13). Setiap siklus dalam penelitian ini terdiri atas dua kali pertemuan dengan alokasi waktu tiap pertemuan 2 x 40 menit. Tahapan-tahapan ini berlangsung secara berulang-ulang, sampai tujuan penelitian tercapai.

Waktu dan Tempat Penelitian

Penelitian dilaksanakan pada bulan JuliOktober 2013. Pelaksanaan tindakan dilakukan pada bulan Oktober 2013. Penelitian dilaksanakan sejalan dengan proses pembelajaran yang sedang berlangsung, yaitu 4 jam pelajaran seminggu dengan 2 kali pertemuan masing-masing siklus. Penelitian dilaksanakan di SMP Negeri 2 Sukoharjo Kabupaten Wonosobo, Provinsi Jawa Tengah. SMP Negeri 2 Sukoharjo Kabupaten Wonosobo beralamat di Desa Jebeng Plampitan, Kecamatan Sukoharjo, Kabupaten Wonosobo, Provinsi Jawa Tengah

\section{Subjek Penelitian}

Subjek penelitian ini adalah siswa kelas VIII B SMP Negeri 2 Sukoharjo, Kabupaten Wonosobo. Alasan dipilih kelas ini adalah didasarkan pada observasi awal siswa kelas VIII $\mathrm{B}$ hasil belajar rendah, nilai rata-rata ulangan harian mata pelajaran IPS 65,58. Dari 22 siswa yang mencapai Kriteria Ketuntasan Minimal (KKM) hanya 10 siswa atau $45,45 \%$, sedangkan 12 siswa atau $54,55 \%$ belum mencapai KKM.

Prosedur Penelitian

Prosedur penelitian tindakan kelas dilaksanakan secara siklus yang berlangsung berkesinambungan Masing-masing siklus dengan menggunakan langkah-langkah sebagai berikut:

\section{Perencanaaan (plan)}

Membuat perecanaan pembelajaran, yaitu: menyiapkan silabus, RPP, dan menyiapkan media pembelajaran. Selain itu, peneliti juga menyiapkan instrumen pengumpulan data, yaitu: pedoman observasi, soal tes hasil belajar, pedoman angket, lembar daftar nama siswa kelas VIII-B, lembar rekapitulasi nilai, dan lembar catatan lapangan.

\section{Pelaksanaan dan Observasi (Act \& Observe)}

Pelaksanaan tindakan pada penelitian ini terdiri atas 2 siklus. Siklus I terdiri atas dua kali pertemuan, materi permasalahan kuantitas dan kualitas penduduk Indonesia dan dampaknya terhadap pembangunan. Media yang digunakan pada siklus I adalah gambar diam, hand out, dan peta konsep bergambar. Siklus II juga terdiri atas dua kali pertemuan dengan materi permasalahan lingkungan hidup dan upaya penanggulangannya dalam pembangunan berkelanjutan. Media yang digunakan pada siklus II yaitu; video, hand out, dan peta konsep bergambar.

Pada tahap ini kolaborator melakukan pengamatan (observe) proses pembelajaran, apa yang dilakukan oleh peneliti dan siswa. Pengamatan tersebut meliputi bagaimana aktivitas siswa, dan aktivitas guru dalam menggunakan model think pair share berbantuan media selama pelaksanaan pembelajaran. Pengamatan dilakukan selama proses pembelajaran dengan menggunakan pedoman observasi yang telah disiapkan dan mencatat kejadian-kejadian yang tidak terdapat dalam lembar observasi dengan membuat lembar catatan lapangan juga dibantu dengan alat dokumentasi yaitu camera.

\section{Refleksi (Reflection)}

Kegiatan refleksi dilakukan dengan cara diskusi dengan kolaborator untuk mengklarifikasi proses pembelajaran, sudah sesuai dengan 
perencanaan atau belum dan hasil belajarnya sudah tercapai atau belum dengan tujuan atau tindakan harus diadakan revisi untuk kegiatan yang akan datang. Berdasarkan hasil refleksi pada siklus I kemudian disusun rencana tindakan selanjutnya untuk perbaikan atas kelemahan dari tindakan sebelumnya.

\section{Teknik dan Instrumen Pengumpulan Data}

Teknik dan instrumen pengumpulan data dengan menggunakan observasi, angket, tes hasil belajar, catatan lapangan, dan dokumentasi.

\section{Teknik Analisis Data}

Teknik analisis data yang digunakan dalam penelitian ini adalah deskriptif kuantitatif. Analisis data deskriptif kuantitatif digunakan untuk memberikan gambaran tentang kemajuan perkembangan aktivitas, sikap, dan hasil belajar siswa, baik secara individu maupun kelas. Aktivitas siswa yang diamati meliputi 8 aspek yaitu: membaca materi, bertanya, memperhatikan materi, mencatat hasil diskusi, mengerjakan tugas tertulis individu, presentasi, semangat dalam mengikuti pelajaran, dan membuat peta konsep bergambar. Angket sikap untuk mengukur hasil belajar ranah afektif, terdapat tiga indikator yaitu kognisi, afeksi, dan konasi dengan 20 butir pernyataan. Sedangkan soal tes untuk mengukur hasil belajar ranah kognitif.

\section{Hasil Penelitian dan Pembahasan}

Penelitian ini menggunakan model Think Pair Share berbantuan media yang dilaksanakan selama dua siklus.

\section{Aktivitas Belajar Siswa}

Data hasil belajar psikomotor berupa aktivitas belajar siswa kelas VIII B SMP N 2 Sukoharjo Kabupaten Wonosobo selama pembelajaran dengan menggunakan model pembelajaran kooperatif think pair share berbantuan media gambar diam (siklus I), dan video (siklus II). Data diambil menggunakan panduan observasi dengan cara memberikan skor pada 8 aspek aktivitas belajar siswa sesuai dengan kriteria yang telah ditentukan. Aktivitas belajar siswa yang diamati yaitu: membaca materi, bertanya, memperhatikan materi, mencatat hasil diskusi, mengerjakan tugas tertulis individu, presentasi, semangat dalam mengikuti pelajaran, dan membuat peta konsep bergambar.
Aktivitas siswa selama proses pembelajaran mengalami peningkatan. Peningkatan aktivitas siswa merupakan salah satu indikator keberhasilan pelaksanaan model pembelajaran Think Pair Share berbantuan media. Selain itu, peningkatan aktivitas belajar siswa juga merupakan indikator adanya perbaikan kualitas proses pembelajaran IPS. Peningkatan aktivitas siswa secara keseluruhan dapat dilihat pada tabel berikut:

Tabel 1. Nilai Aktivitas Siswa Siklus I \& II

\begin{tabular}{|c|c|c|c|}
\hline \multirow{2}{*}{ No } & \multirow{2}{*}{$\begin{array}{l}\text { Aspek yang } \\
\text { diamati }\end{array}$} & \multicolumn{2}{|c|}{ Nilai Rata-Rata } \\
\hline & & Siklus I & Siklus II \\
\hline 1 & Membaca Materi & 72,73 & 84,55 \\
\hline 2 & Bertanya & 59,55 & 82,73 \\
\hline 3 & $\begin{array}{l}\text { Memperhatikan } \\
\text { Materi }\end{array}$ & 68,64 & 80 \\
\hline 4 & $\begin{array}{l}\text { Mencatat Hasil } \\
\text { Diskusi }\end{array}$ & 66,82 & 76,82 \\
\hline 5 & $\begin{array}{l}\text { Mengerjakan } \\
\text { Tugas Tertulis } \\
\text { Individu }\end{array}$ & 70,91 & 85,91 \\
\hline 6 & Presentasi & 65,91 & 75 \\
\hline 7 & $\begin{array}{l}\text { Semangat Dalam } \\
\text { Mengikuti } \\
\text { Pelajaran }\end{array}$ & 67,27 & 75,91 \\
\hline 8 & $\begin{array}{l}\text { Membuat Peta } \\
\text { Konsep Bergambar }\end{array}$ & 70,91 & 88,64 \\
\hline \multicolumn{2}{|c|}{ Rata-Rata } & 67,84 & 81,2 \\
\hline \multicolumn{2}{|c|}{ Kategori } & Cukup & Baik \\
\hline
\end{tabular}

Data peningkatan aktivitas siswa dari siklus I Sampai dengan siklus II disajikan pada grafik berikut:

Aktivitas siswa selama proses pembelajaran mengalami peningkatan, pada siklus I nilai ratarata aktivitas siswa kategori cukup yakni 67,84. Aktivitas pada siklus II kategori baik sebesar 81,20 terjadi peningkatan $13,36(19,69 \%)$ dari siklus I.

Berdasarkan hasil penelitian pada siklus I sampai siklus II, aktivitas siswa mengalami peningkatan pada setiap siklusnya. Hal ini merupakan hasil dari refleksi yang memperhatikan kelemahan-kelemahan pada kondisi nyata siklus sebelumnya. Kelemahan-kelemahan pada siklus sebelumnya dijadikan fokus untuk melakukan perbaikan pada siklus berikutnya. 
Penerapan model pembelajaran Think Pair Share berbantuan media ternyata dapat meningkatkan aktivitas siswa. Peningkatan terjadi karena kinerja guru dalam mengaplikasikan model pembelajaran Think Pair Share berbantuan media yang semakin baik. Pada setiap siklus, siswa semakin memahami tahapan pembelajaran menggunakan model Think Pair Share baik pada kegiatan berpikir (thinking), berpasangan (pairing), dan berbagi (sharing) sehingga siswa dapat memahami apa yang harus dilakukan pada setiap tahapan pembelajaran. Peningkatan aktivitas siswa juga dikarenakan adanya media pembelajaran yang bervariasi. Pada siklus I guru menggunakan media gambar diam, ternyata belum semua siswa berpartisipasi aktif dalam pembelajaran. Pada siklus II guru menggunakan media video dan ternyata aktivitas siswa mengalami peningkatan yang signifikan dibandingkan dengan siklus I. Penggunaan media video juga mampu mengurangi siswa dari kebosanan, kejenuhan serta meningkatkan aktivitas dan partisipasi aktif siswa dalam pembelajaran. Dengan demikian, penggunaan media video dalam pembelajaran IPS terbukti lebih efektif untuk meningkatkan aktivitas belajar siswa (hasil belajar psikomotor).

Setiap indikator dari masing-masing aspek yang diamati pada siklus I sampai dengan siklus II juga mengalami peningkatan. Aktivitas belajar mandiri siswa berdasarkan aktivitas visual (visual activities) yang meliputi membaca materi pada siklus I termasuk dalam kategori baik dan terus mengalami peningkatan pada siklus II sehingga menjadi sangat baik. Pada siklus I dengan menggunakan media gambar diam, nilai rata-rata aktivitas visual sebesar 72,73 dan pada siklus II dengan menggunakan media video menjadi 84,55 atau mengalami peningkatan $11,82(16,25 \%)$ dari siklus I. Kesempatan siswa untuk bekerja sendiri dalam proses pembelajaran menggunakan model think pair share, membuat siswa memiliki waktu lebih lama untuk berpikir (thinking) dalam membaca materi dan mengembangkan pemahamannya tentang materi yang dipelajari. Dengan demikian, penerapan model pembelajaran kooperatif think pair share berbantuan media terutama media video pada siklus II dapat meningkatkan aktivitas belajar mandiri siswa berdasarkan aktivitas visual (visual activities) tertutama dalam aspek kegiatan membaca materi.
Peningkatan aktivitas visual yang terjadi pada setiap siklus bukan tanpa kekurangan atau kelemahan. Beberapa kekurangan yang terjadi antara lain: (1) terdapat siswa yang kurang serius dalam membaca materi yaitu ada siswa yang bermain dan bercanda dengan temannya ketika diminta untuk mempelajari materi. (2) sebagian siswa belum memanfaatkan alokasi waktu yang tersedia untuk membaca materi pelajaran. (3) terdapat siswa yang hanya membaca sekilas materi pelajaran dan tidak mengulang kembali mempelajari materi, sehingga siswa tidak sepenuhnya memahami materi pelajaran.

Aktivitas oral (oral activities) siswa yang berupa aktivitas bertanya juga mengalami peningkatan. Pada siklus I dengan media gambar diam, rata-rata nilai aktivitas oral sebesar 59,55 atau berada pada kategori cukup dan pada siklus II menggunakan media video menjadi 82,73 atau mengalami peningkatan $23,18 \quad(38,93 \%)$ dari siklus I. Dengan demikian, pada siklus II melalui penggunaan media video, aktivitas bertanya termasuk dalam kategori baik. Peningkatan aktivitas bertanya terjadi karena guru dengan serius memberikan motivasi dan membimbing siswa sehingga tidak lagi merasa takut dan malu untuk bertanya. Pada awalnya untuk memancing siswa supaya mau bertanya guru memberikan reward (hadiah) berupa 1 buah ballpoint kepada siapa saja yang mau untuk bertanya atau menanggapi pertanyaan teman lainnya. Dengan cara ini, pada pertemuan berikutnya siswa menjadi lebih aktif bertanya meskipun tidak lagi diberikan hadiah oleh guru. Peningkatan aktivitas bertanya juga terjadi karena siswa sudah memiliki pengetahuan awal yang berasal dari aktivitas membaca materi, siswa mulai bertanya terhadap materi yang belum dipahami dan bertanya tentang permasalahan dalam menyelesaikan diskusi bersama kelompoknya.

Aktivitas mendengarkan (listening activities) yang meliputi kegiatan memperhatikan materi dengan model pembelajaran think pair share berbantuan media juga mengalami peningkatan. Pada siklus I menggunakan media gambar diam, aktivitas memperhatikan materi nilai rataratanya sebesar 68,64 atau termasuk kategori baik dan pada siklus II dengan menggunakan media video menjadi 80,00 atau meningkat 11,36 
$(16,55 \%)$ dari siklus sebelumnya. Peningkatan listening activities disebabkan karena siswa tertarik dengan media yang digunakan oleh guru yaitu pada siklus I menggunakan gambar diam tentang permasalahan kuantitas dan kualitas penduduk di Indonesia yang ditempel dengan kertas manila serta dipajang di depan kelas sehingga membuat siswa penasaran ingin mengetahuinya. Pada siklus II guru menggunakan video tentang permasalahan lingkungan hidup dan upaya penanggulangannya dalam pembangunan berkelanjutan yang ditayangkan dengan LCD proyektor sehingga siswa lebih serius dan tidak merasa bosan dalam memperhatikan materi. Dengan demikian, penggunaan media video yang dipadukan dengan model pembelajaran Think Pair Share ternyata lebih efektif dalam meningkatkan aktivitas memperhatikan materi.

Penerapan model pembelajaran Think Pair Share berbantuan media video memberikan peningkatan aktivitas belajar siswa berdasarkan aktivitas menulis (writing activities) yang meliputi mencatat hasil diskusi dan mengerjakan tugas tertulis individu. Pada aspek mencatat hasil diskusi siklus I nilai rata-ratanya adalah 66,82 dan pada siklus II 76,82 atau meningkat 10,00 $(14,97 \%)$ sehingga termasuk kategori baik. Aspek mengerjakan tugas tertulis individu nilai rata-rata yang diperoleh siswa pada siklus I sebesar 70,91 kategori baik menjadi 85,91 pada siklus II atau mengalami peningkatan 15,00 (21,15\%) sehingga termasuk kategori sangat baik. Secara keseluruhan nilai rata-rata aktivitas menulis (writing activities) dari aspek mencatat hasil diskusi dan mengerjakan tugas individu pada siklus II adalah 81,37 termasuk dalam kategori baik. Peningkatan aktivitas menulis terjadi karena guru selalu memberikan arahan kepada siswa untuk mencatat halhal penting selama pembelajaran berlangsung dan meminta siswa untuk rajin mengerjakan tugas-tugas yang diberikan guru sebagai latihan sehingga pada waktu dilakukan penilaian, siswa dapat mengerjakan soal dengan baik. Selain itu, mulai tumbuh kesadaran siswa untuk mencatat istilah-istilah penting dan perlunya mengerjakan tugas tertulis untuk membantu mempermudah siswa dalam memahami dan mendalami materi pelajaran.
Peningkatan aktivitas belajar siswa juga terjadi pada aktivitas presentasi berdasarkan motor activities. Nilai rata-rata yang diperoleh siswa pada siklus I dengan media gambar diam adalah 65,91 dan pada siklus II menggunakan media video menjadi 75,00 baik pada siklus I maupun siklus II termasuk kategori baik. Peningkatan aktivitas presentasi sebesar 9,09 (13,79\%) dari siklus I. Aktivitas presentasi termasuk salah satu tahapan penting dalam penerapan model pembelajaran Think Pair Share. Aktivitas presentasi termasuk tahapan terakhir yaitu berbagi (sharing). Kegiatan presentasi memberikan manfaat kepada siswa yaitu membuat siswa berani mengemukakan pendapatnya dan saling bertukar pendapat antar kelompok. Siswa dapat mengetahui pendapat dari kelompok lain dan membandingkan dengan jawaban kelompoknya kemudian saling melengkapi pendapatnya masing-masing. Selain itu, kegiatan presentasi dapat melatih siswa untuk lebih aktif dan berani berbicara dihadapan temannya.

Peningkatan aktivitas presentasi terjadi tidak lepas dari peran guru sebagai motivator dan moderator pada kegiatan ini. Guru memberikan apresiasi terhadap siswa yang aktif dalam mempresentasikan hasil diskusi kelompok (pasangannya) serta kepada kelompok lain yang memberikan masukan, sanggahan, dan tanggapan kepada kelompok lainnya. Selain itu, peningkatan aktivitas presentasi juga disebabkan karena mulai munculnya keberanian siswa untuk mewakili kelompoknya dalam rangka berbagi (sharing) pengetahuan sesuai tugas yang diberikan kepada setiap kelompok.

Peningkatan aktivitas presentasi (sharing) dalam proses pembelajaran pada setiap siklus juga masih disertai kekurangan dan kelemahan antara lain: (1) ada siswa yang kurang aktif dalam kegiatan presentasi serta mengandalkan rekan sekelompoknya untuk mengemukakan pendapat. (2) pendapat dari masing-masing siswa yang mewakili kelompoknya hampir sama satu sama lain.

Emotional activities yang salah satu aspeknya yaitu semangat dalam mengikuti pelajaran juga mendapatkan efek positif dari penerapan model pembelajaran think pair share 
berbantuan media. Nilai rata-rata kelas aktivitas semangat dalam mengikuti pelajaran IPS pada siklus I sebesar 67,27 meningkat menjadi 75,91 atau termasuk dalam kategori baik. Peningkatan akivitas semangat dalam mengikuti pelajaran IPS dari siklus I ke siklus II adalah 8,64 (12,84\%). Peningkatan emotional activities berupa semangat dalam mengikuti pelajaran IPS terjadi karena siswa merasa senang terhadap model pembelajaran think pair share berbantuan media. Bagi siswa think pair share merupakan sesuatu yang baru karena sebelumnya belum pernah dipergunakan oleh guru IPS maupun guru lainnya.

Penggunaan media yang bervariasi pada setiap siklus juga membuat siswa merasa senang untuk belajar IPS. Pada siklus I guru menggunakan media gambar diam, dan pada siklus II menggunakan media video. Penggunaan media video pada siklus II berhasil menghilangkan kesan bahwa IPS hanya sekedar pelajaran hafalan yang membosankan. Dengan demikian, meningkatnya semangat siswa dalam mengikuti pelajaran IPS disebabkan karena ketertarikan siswa terhadap penerapan model pembelajaran Think Pair Share serta penggunaan media video pada siklus II.

Aktifitas membuat peta konsep bergambar yang merupakan salah satu aspek dari drawing activities juga mengalami peningkatan. Pada siklus I menggunakan media gambar diam, nilai rata-rata aktivitas membuat peta konsep bergambar sebesar 70,91 termasuk dalam kategori baik menjadi 88,64 pada siklus II dengan menggunakan media video atau mengalami peningka$\tan 17,73(25,00 \%)$ dan termasuk kategori sangat baik. Peningkatan aktivitas semangat dalam mengikuti pelajaran terjadi karena guru selalu memberikan bimbingan, dan arahan dalam membuat peta konsep bergambar yang baik.

Berdasarkan paparan tersebut dapat dikemukakan bahwa penerapan model pembelajaran think pair share berbantuan media terutama media video pada siklus II dapat meningkatkan aktivitas belajar siswa dalam pembelajaran IPS. Hal itu sesuai dengan pendapat Piaget (Sardiman, 2011: 100) tentang prinsip aktivitas bahwa "seorang anak itu berpikir sepanjang ia berbuat, tanpa berbuat berarti anak itu tidak berpikir". Dengan demikian, melalui penerapan model pembalajaran think pair share berbantuan media video dapat meningkatkan aktivitas belajar siswa secara keseluruhan.

\section{Sikap Siswa (Hasil Belajar Afektif)}

Hasil belajar afektif berupa sikap siswa terhadap materi pelajaran IPS melalui penerapan model pembelajaran Think Pair Share berbantuan media. Data hasil belajar afektif diperoleh dari angket sikap siswa terhadap materi pelajaran IPS yang terdiri dari 20 butir pernyataan. Pernyataan angket disusun secara proporsional antara pernyataan positif dengan negatif, yaitu masing-masing 10 pernyataan. Pernyataan angket juga diklasifikasikan menjadi 3 aspek yaitu aspek kognisi atau pengetahuan dan pemahaman siswa terhadap pelajaran IPS yang terdiri dari 7 butir soal (4 positif \& 3 negatif), aspek afeksi atau emosi/perasaan yang timbul terhadap pelajaran IPS yang terdiri dari 6 butir soal (3 positif \& 3 negatif), dan aspek konasi atau kecenderungan bertindak terhadap pelajaran IPS yang terdiri dari 7 butir soal ( 3 positif \& 4 negatif). Data hasil belajar ranah afektif siklus I sampai dengan siklus II dapat disajikan pada tabel berikut:

Tabel 2. Nilai Sikap Siswa Siklus I \& II

\begin{tabular}{cccc}
\hline \multirow{2}{*}{ No } & Aspek & \multicolumn{2}{c}{ Nilai } \\
\cline { 3 - 4 } & & Siklus I & Siklus II \\
\hline 1 & Kognisi & 77,27 & 84,42 \\
2 & Afeksi & 75,76 & 83,33 \\
3 & Konasi & 78,57 & 85,06 \\
\hline Rata-Rata & $\mathbf{7 7 , 2}$ & $\mathbf{8 4 , 4 9}$ \\
\hline Kategori & Baik & Sangat Baik \\
\hline
\end{tabular}

Dari tabel 2 diperoleh sikap siswa tehadap materi pelajaran IPS menggunakan model pembelajaran Think Pair Share berbantuan media. Rata-rata sikap siswa pada siklus I dengan media gambar diam 77,20. Sikap siswa pada siklus II dengan media video 84,30 meningkat 9,48\% dari siklus I. Peningkatan ini terjadi karena penguasaan guru terhadap model pembelajaran Think Pair Share semakin baik, sehingga pembelajaran menjadi lancar. Siswa tertarik dengan tahapan-tahapan pembelajaran baik berpikir (thinking), berpasangan (pairing), dan berbagi (sharing) selama proses pembelajaran berlangsung. Pemahaman siswa terhadap materi bermanfaat terhadap peningkatan aktivitas belajar. 
Penggunaan media yang bervariasi yaitu media gambar diam (still picture) yang dipadukan dengan peta konsep bergambar pada siklus I dan media video yang dipadukan dengan peta konsep bergambar terbukti dapat meningkatkan pemahaman siswa terhadap materi yang disampaikan guru. Namun demikian, media video yang digunakan ternyata lebih efektif meningkatkan hasil belajar afektif karena pada siklus II nilai sikap siswa termasuk kategori sangat baik.

Di antara ketiga aspek sikap atau hasil belajar afektif ternyata aspek konasi memiliki ratarata nilai paling tinggi. Hal ini terjadi karena siswa cenderung bertindak dan aktif selama pembelajaran berlangsung. Siswa sangat antusias selama pembelajaran IPS, sehingga kecenderungan melakukan aktivitas tergolong tinggi. Peningkatan juga terjadi karena penguasaan guru terhadap pembelajaran menggunakan model Think Pair Share berbantuan media dengan baik.

Siswa semangat dalam kegiatan berpikir (thinking) mengerjakan tugas secara individual, berdiskusi dengan pasangannya (pairing) dalam menyelesaikan tugas membuat peta konsep bergambar secara berkelompok, dan pada kegiatan berbagi (sharing) untuk mempresentasikan hasil diskusi kelompoknya. Data peningkatan dari siklus I sampai dengan siklus II disajikan pada grafik berikut:

Kriteria keberhasilan tindakan ditetapkan apabila rata-rata sikap siswa mencapai $>68$ atau termasuk kategori baik. Dengan demikian, capaian sikap siswa terhadap materi IPS model pembelajaran Think Pair Share berbantuan media telah melampaui kriteria keberhasilan tindakan yang telah ditetapkan.

\section{Hasil Belajar Kognitif}

Data hasil belajar kognitif berupa tes hasil belajar yang dilakukan di setiap akhir pertemuan pada setiap siklus berupa bahasan satu tema pembelajaran IPS. Penilaian hasil belajar kognitif dilakukan dengan memberikan tes hasil belajar menggunakan bentuk soal pilihan ganda sebanyak 20 butir soal, pada siklus I maupun siklus II. Data

Hasil belajar kognitif mengalami peningkatan di setiap siklusnya, seperti terlihat pada tabel berikut:
Tabel 3. Hasil Belajar Kognitif Siklus I \& II

\begin{tabular}{cccc}
\hline \multirow{2}{*}{ No } & \multirow{2}{*}{ Uraian } & \multicolumn{2}{c}{ Hasil Belajar } \\
\cline { 3 - 4 } & & Siklus I & Siklus II \\
\hline 1 & Nilai terendah & 60 & 65 \\
2 & Nilai tertinggi & 90 & 100 \\
3 & Nilai rata-rata & 79,1 & 85,9 \\
\hline
\end{tabular}

Dari tabel 3 dapat diketahui bahwa nilai rata-rata hasil belajar siklus I sebesar 79,10 dan pada siklus II menjadi 85,90 atau meningkat $8,59 \%$. Data peningkatan hasil belajar kognitif sebagai berikut:

Peningkatan hasil belajar kognitif berkaitan dengan semakin meningkatnya kemampuan serta penguasaan guru terhadap model pembelajaran Think Pair Share berbantuan media sehingga proses pembelajaran IPS berlangsung dengan baik.

Kemampuan guru dalam pengelolaan kelas mendorong partisipasi aktif siswa serta meningkatkan aktivitas siswa selama proses pembelajaran IPS di kelas VIII B berlangsung. Penggunaan media yang bervariasi ternyata mampu meningkatkan pemahaman siswa terhadap materi pembelajaran, peningkatan aktivitas belajar, sikap siswa, dan memberikan efek positif terhadap peningkatan hasil belajar kognitif. Selain itu, cara pengambilan penilaian yang dilakukan guru juga berpengaruh terhadap peningkatan hasil belajar kognitif. Dengan memberikan penilaian pada setiap akhir pertemuan maka beban belajar siswa menjadi tidak terlalu berat sehingga dapat memperoleh nilai yang maksimal dan mencapai ketuntasan belajar baik secara individual maupun klasikal.

Peningkatan hasil belajar kognitif di kelas VIII B juga terjadi karena motivasi yang diberikan guru, semangat siswa dalam mengikuti pembelajaran, dan proses pembelajaran yang menyenangkan dengan model serta media yang menarik perhatian siswa. Pada siklus I dengan menggunakan media gambar diam terjadi peningkatan hasil belajar kognitif dibandingkan dengan kondisi awal (pratindakan), akan tetapi belum sesuai dengan kriteria keberhasilan tindakan. Pada siklus II melalui penggunaan media video terjadi peningkatan hasil belajar kognitif yang signifikan sehingga ketuntasan belajar 
siswa dapat tercapai. Dengan demikian, dapat disimpulkan bahwa melalui penerapan model pembalajaran Think Pair Share dengan media video ternyata lebih efektif meningkatkan hasil belajar kognitif pada kelas VIII B di SMP Negeri 2 Sukoharjo Kabupaten Wonosobo.

Kriteria keberhasilan tindakan yang ditetapkan untuk hasil belajar kognitif adalah apabila secara individual siswa mendapatkan nilai $\geq 77$ dan ketuntasan klasikal apabila $\geq 85 \%$ siswa telah mencapai KKM/telah tuntas belajar. Berdasarkan ketuntasan belajar pada siklus II sebesar 90,90\% maka penelitian ini telah mencapai kriteria keberhasilan tindakan.

Aktivitas Guru dalam Pelaksanaan Model Pembelajaran Think Pair Share Berbantuan Media

Data aktivitas guru diperoleh melalui observasi selama pembelajaran dengan indikator seperti pada lampiran 6a halaman 236. Data kinerja guru dari siklus I sampai siklus II dapat disajikan pada tabel berikut:

Tabel 4. Pelaksanaan Model Think Pair Share Berbantuan Media Siklus I\&II

\begin{tabular}{llcc}
\hline \multirow{2}{*}{ No } & \multirow{2}{*}{ Kegiatan } & \multicolumn{2}{c}{ Nilai } \\
\cline { 3 - 4 } & & Siklus I & Siklus II \\
\hline 1 & Pendahuluan & 83,33 & 91,67 \\
2 & Inti & 85 & 100 \\
3 & Penutup & 87,5 & 100 \\
\hline Rata-Rata & $\mathbf{8 5 , 2 8}$ & $\mathbf{9 7 , 2 2}$ \\
\hline Kategori & Sangat Baik & Sangat Baik
\end{tabular}

Aktivitas guru pada siklus I rata-rata 85,28 kategori sangat baik. Pada siklus II rata-rata aktivitas guru 97,22 termasuk kategori sangat baik dan terjadi peningkatan sebesar $11,94 \%$ dari siklus I.

Peningkatan aktivitas guru terjadi karena guru telah mampu menguasai model pembelajaran think pair share dan media dengan baik sehingga pembelajaran IPS dapat berlangsung dengan baik. Semua tahapan pembelajaran dari kegiatan pendahuluan, inti, dan penutup dapat dilaksanakan guru dengan sangat baik dari siklus I sampai dengan siklus II. Kegiatan yang dilakukan guru pada kegiatan pendahuluan adalah membuka pelajaran dengan salam dan doa, memeriksa kesiapan belajar siswa meliputi kebersihan dan kerapihan, memusatkan perhatian siswa dengan menggunakan media yang telah disiapkan oleh guru yaitu gambar diam (still picture) pada siklus I dan video pada siklus II, memberikan apersepsi dan motivasi dengan pendekatan kontekstual sehingga pembelajaran menjadi lebih bermakna, menjelaskan kompetensi dasar dan tujuan pembelajaran, dan menjelaskan langkah-langkah model pembelajaran think pair share.

Kegiatan inti yang dilakukan guru antara lain: menyampaikan materi pokok secara logis dan singkat, membimbing siswa dalam kegiatan berpikir (thinking), diskusi secara berpasangan (pairing), dan presentasi atau berbagi (sharing). Pada kegiatan inti guru juga memberikan kesempatan kepada siswa untuk bertanya jawab sehingga melatih siswa untuk turut berpartisipasi secara aktif dalam kegiatan pembelajaran. Guru juga membimbing siswa untuk menghasilkan ide gagasan yang kreatif dalam menyelesaikan tugas untuk membuat peta konsep bergambar yang berfungsi sebagai media yang dibuat sendiri oleh siswa. Sebagai kunci keberhasilan pembelajaran, maka pada kegiatan inti guru mengalokasikan waktu yang lebih lama namun tetap memperhatikan pengaturan waktu dengan baik agar tujuan pembelajaran dapat terlaksana dan tercapai dengan baik.

Pada kegiatan penutup, aktivitas yang dilakukan guru antara lain: membimbing siswa membuat kesimpulan materi yang telah dipelajari serta berdasarkan hasil diskusi kelompok, memberikan penilaian dan penugasan kepada siswa, melakukan refleksi dan mengakhiri pembelajaran dengan do'a dan salam.

Berdasarkan paparan tersebut dapat disimpulkan bahwa penerapan model pembelajaran Think Pair Share berbantuan media video pada siklus II lebih efektif dibandingkan media gambar diam untuk meningkatkan hasil belajar siswa di kelas VIII B SMP Negeri 2 Sukoharjo, Kabupaten Wonosobo. Dengan demikian, model Think Pair Share berbantuan media video dapat dijadikan alternatif pemilihan model dan media yang tepat untuk dikembangkan dalam pembelajaran IPS.

Peningkatan aktivitas guru selama pelaksanaan tindakan juga disebabkan karena kemampuan guru dalam memainkan peran yang baik 
sebagai pembimbing, fasilitator, dan motivator kepada siswa selama proses pembelajaran berlangsung. Dengan demikian, dapat disimpulkan bahwa keberhasilan pelaksanaan tindakan yang dilaksanakan guru karena guru sudah memiliki pengetahuan, dan kemampuan yang baik dalam menerapkan model pembelajaran think pair share dan media pembelajaran yang relevan. Peningkatan aktivitas guru pada siklus I dan II disajikan pada grafik berikut:

\section{Simpulan dan Saran}

Simpulan

Berdasarkan hasil penelitian dan pembahasan yang diperoleh selama penerapan model pembelajaran Think Pair Share berbantuan media pada pembelajaran IPS di kelas VIII B SMP Negeri 2 Sukoharjo Kabupaten Wonosobo dapat disimpulkan sebagai berikut:

1. Penerapan model pembelajaran Think Pair Share berbantuan media dapat meningkatkan aktivitas belajar siswa. Nilai rata-rata aktivitas belajar siswa pada siklus I sebesar 67,84 dengan kategori cukup dan pada siklus II menjadi 81,20 dengan kategori baik. Aktivitas belajar siswa pada siklus II dengan media video mengalami peningkatan sebesar 19,69\% dari siklus I. Dengan demikian, model think pair share berbantuan media video dapat dijadikan alternatif pemilihan model dan media yang tepat untuk dikembangkan dalam pembelajaran IPS karena dapat meningkatkan aktivitas belajar siswa.

2. Penerapan model pembelajaran Think Pair Share berbantuan media dapat meningkatkan nilai sikap siswa (hasil belajar afektif). Pada siklus I nilai rata-rata hasil belajar afektif adalah 77,20 dengan kategori baik dan pada siklus II menjadi 84,49 termasuk dalam kategori sangat baik. Hasil belajar afektif mengalami peningkatan sebesar 9,48\% dari siklus I. Dari hasil penelitian ini dapat diketahui, bahwa penggunaan media video pada model TPS dapat meningkatkan ketertarikan siswa belajar IPS sehingga proses pembelajaran menjadi lebih menyenangkan.
3. Penerapan model pembelajaran Think Pair Share berbantuan media dapat meningkatkan hasil belajar ranah kognitif. Nilai ratarata hasil belajar kognitif pada siklus I 79,10 dan siklus II sebesar 85,90 mengalami peningkatan $8,59 \%$ dari siklus I. Ketuntasan belajar klasikal siklus I 77,30\% (17 dari 22 siswa tuntas belajar) dan pada siklus II $90,90 \%$ (20 dari 22 siswa tuntas belajar). Dengan demikian, model pembelajaran think pair share berbantuan media cocok untuk digunakan sebagai upaya peningkatan hasil belajar kognitif.

Saran

1. Guru

a. Memanfaatkan hasil penelitian ini dalam memilih model pembelajaran, karena model Think Pair Share dapat meningkatkan aktivitas siswa, sikap, dan hasil belajar.

b. Guru hendaknya mampu menguasai langkah-langkah model pembelajaran Think Pair Share dengan baik dan mampu memilih media yang tepat sesuai dengan materi dan tujuan pembelajaran.

c. Guru lebih kreatif dalam memilih, membuat, dan menggunakan media pembelajaran agar suasana pembelajaran lebih menyenangkan.

2. Sekolah

a. Model pembelajaran Think Pair Share berbantuan media dapat digunakan oleh guru untuk merencanakan dan melaksanakan pembelajaran sehingga membantu upaya sekolah meningkatkan kualitas pembelajaran pada khususnya serta kualitas sekolah pada umumnya.

b. Sekolah dengan fasilitas yang memadadai di bidang informasi dan telekomunikasi hendaknya menyediakan media pembelajaran IPS yang lebih lengkap dengan berbasis teknologi informasi dan komunikasi untuk peningkatan kualitas pembelajaran. 
c. Sekolah dengan fasilitas yang belum memadai di bidang informasi dan komunikasi hendaknya mampu secara kreatif dan inovatif membuat dan mengembangkan media pembelajaran.

3. Peneliti Lain

Kepada peneliti lain yang ingin melakukan penelitian tsejenis hendaknya terlebih dahulu menganalisis model dan media untuk disesuaikan dengan penerapannya, terutama dalam hal alokasi waktu, fasilitas pendukung, media pembelajaran, dan karakteristik siswa. Dengan demikian, diharapkan hasil penelitian yang dilakukan akan lebih baik.

\section{Daftar Pustaka}

Arends, R.I. (2012). Learning to teach. ninth edition. New York: McGraw Hill Companies.

Davidson, N \& Kroll, D. L. (1991). An Overview of Research on Cooperative Learning Related to Mathematics. Journal for Research in Mathematics Education. 262.

Heinich, R. et al. (1996). Instructional media and technologies for learning. London: Pearson Merrill Prentice Hall.

Joyce, B \& Weil, M. (2003). Model of teaching. Allyn and Bacon A Simon \& Scuster Company.

Kemmis, S \& Taggart, Mc.R. (1990). The action research planner. Deakin University.

Lie, A. (2003). Cooperative learning mempraktikkan cooperative learning di ruangruang kelas. Jakarta: Grasindo.
Mardapi, D. (2012). Pengukuran, penilaian dan evaluasi pendidikan. Yogyakarta: Nuha Medika.

NCSS (National council for the social studies). Diakses tanggal 28 Oktober 2012 dari http://www.socialstudies.org/about.

Rusman. (2011). Model-model pembelajaran; mengembangkan profesionalisme guru. Jakarta : Rajawali Press.

Sanjaya, W. (2012). Strategi pembelajaran berorientasi standar proses pendidikan edisi pertama. Jakarta: Kencana Prenada Media Grup.

Sardiman, A.M. (2011). Interaksi dan motivasi belajar mengajar. Jakarta: Raja Grafindo Persada.

Slavin, R.E (1995). Cooperative learning; theory, research and practise. Boston: Allyn \& Bacon.

Trianto. (2012). Model pembelajaran terpadu konsep, strategi dan implementasinya dalam KTSP. Jakarta: Bumi Aksara.

Undang-Undang RI No.20 Tahun 2003, tentang Sistem Pendidikan Nasional.

Uno, H.B \& Muhamad, N. (2012). Belajar dengan pendekatan PAILKEM: pembelajaran aktif, inovatif, lingkungan, kreatif, efektif, menarik. Jakarta: Bumi Aksara. 